\title{
第158回大腸肛門病瑟談会 主題：「肚門の皮膚病変」
}

\author{
日 時：平成16年3月13日（土） \\ 場 所：社会保険中央総合病院 $4 \mathrm{~F}$ 講堂 \\ 司 会：瀧上 隆夫先生（チクバ外科・胃腸科・肛門科病院）
}

瀧上（隆夫・チクバ外科・胃腸科・肍門科病院・司会）第 158 回大腸肛門病怎談会を開きます。本日のテーマは「肛門の皮膚病変」 で、岩垂先生よりご紹介いただきました社会保険中央総合病院、皮 覻科部長の鳥居先生にアドバイスをお願いしながら会を進めようと 思っております。どうぞ先生よろしくお願いします。

それでは「肛門瘦棒症とその類似疾患一皮唐科学的見地をふまえ た検討一」、大阪肛門病院の佐々木先生よろしくお願いします。

佐々木（美礼・大阪肛門病院）われわれは肚門瘦痒症を皮膚科 学的にとらえ、その定義を明確にし、真の肚門瘦痒症と似たような 症状を呈するものを区別することにより、的確な診断と治療が可能 になり良好な結果を得ましたので報告させていただきます。

（スライド：以下S）明らかな原因が見出せないものを原発性、 原因疾患が明らかなものを続発性として取り扱ってきた例が多く見 られますが、われわれは皮虚科学的定義に従い、いわゆる原発性の もののみを肛門疼嫊症とし、二次性のものはそれの類似疾患として 取り扱っています。日常の診療で最も迷うのが湿疹かカビかという 問題だと思います。もしどちらかわからなければ真菌検査をすれば わかります。外来で最も簡便に行える検查が直接鏡検法ですが、検 体のサイズの仕方によっては直接鏡検で菌が検出できないこともあ りますので、鏡検で出なかったからといって真菌症を否定するので はなく、必ず培盖検査に提出する必要があります。

（S）治療ですが、よくカビか湿疹か診断がつかないので、ステロ イド剂と抗真菌剤を同時に処方したり、混合したりして処方するケ ースを見かけますが、症状が改善しないばかりか正確な診断を妨げ るので、皮屇科学的にはあまりしない方がいいと思われます。真菌 症の疑いがあれば検査をするという手間を惜しんではいけないと思 います。

（S）内服と同じようにステロイド外用剂においても漸減療法を行 いました。最初にstrongクラスの作用の強いものを使用し、皮膚の 炎症やむくみなどの症状を徹底的に抑え、次に作用の弱いものに切 り替えてリバウンドを防止し、ダラダラと長期間にわたってステロ イド剤を使用しないようにします。これを1クールとし、3週間後 に皮疹の改善の有無を判定します。

具体的には最初にリンデロンVG軟高を1週間、次に（アルメタ） 軟䇆を2週間使用しております。また健康保険上では皮膚瘦㾕症に 対して適用が認可されている製剤は少ないですので、処方する場合 には必ず慢性湿疹と病名を記載する必要があるので注意してくださ W。

（S）これはコンジローマなんですが、ところどころに扁平で褐色 の丘骖が見られます。

組織像で、組織学的にはBowen と類似の組織像になります。異 型細胞が散在しています。Bowenoid papulosisは組織学的には悪性、 でも臨床経過は良性ということで、自然消失することも結構あるの で、昔は切除する必要はないという意見が多かったんですが、現在 は切除、焼灼した方がよいと言われております。治療はコンジロー マと同じでよいと思われますが、まれにSCC、扁平上皮癌を発症す ることがあり、子宮頸疽との合併もあるので、注意深い観察が必要 になります。

（S）どのような場合に悪性腫瘍を疑うかというと、浸潤を触れる
皮疹。ステロイドをある程度塗れば改善するんですけど、なかなか 治らない場合は一度疑って生検した方がいいと思われます。

以上です。

吉永（栄一・吉永外科医院） カビがついているかどうか鑑別す るとき皮科の先生方は鏡検すれば大体わかりますけど、肛門科の 先生はちょっと見てもわからないような感じがするんです。できる とすれば培養なんですが、培盖の取り方は。

佐々木 鳞屑といっていますが、先が鈍なメスで、皮居をこそげ 取るようにして取って、それを直接培養の検查に出されてもいいで すし、どうしても取れずにわりとウェッティな感じの浸軟した皮疹 でしたら、綿棒でこすってそれを出すようにしているんですが、培 地とかは個々の施設によって多分違うと思います。皮周科では寒天 培地というのを使っていました。

司会 鳥居先生、何かございますか。

鳥居（秀嗣・社会保險中央総合病院皮成科）確かに鏡検は検体 の採取がやっぱり一番大事で、それで8割がた決まってしまうんで すが、実際的にはカンジタとか白癖の場合は湿疹と比べると少し落 屑が薄く剥がれる感じのものが多いんです。ちょうどめくれるとこ ろ、少しめくっていったところを取るとそこにたくさんいるわけで す。膿疮がある場合は膿疮の膿疮蓋という蓋の部分を取るとそこに はたくさん必ずいます。湿疹と真菌の鑑別は鏡検ができれば一番い いんですが、今回の演題でおっしゃられなかったのは抗真菌剂で接 触皮店炎を起こしてしまうということがあるんですね。そうなると かなり複雑になってきますので、そういう方は1回ちょっと外用を やめてみて、抗真菌剂でもステロイド剂でもないもので短期間やっ てみて、どっちかのクリニカルな症状が起こるというはっきりした 状況にしてもう 1 回調べ直すというのが実際的じゃないかと思いま す。

司会 次は「当院での肚門部皮凨病変」を坂田先生、よろしくお 願いします。

坂田（寛人・坂田肚門科医院）当院での皮疾患は全体の約 6\%ぐらいです。注意している点は湿疹皮膚炎群と悪性の腫瘍群、 難病といわれている皮病変の鑑別をおろそかにしないようにし て、通常の皮虐疾患でしたら肛門疾患を治すことによって続発性の ものは治るし、穏やかな軟衰の使用で治しているわけです。たまに 珍しいものとかちょっと形態の違う色素沈着を伴うもの、潰泀を形 成したものに隆起性のものがあるような、そういうものは悪性を疑 って当院ではbiopsyをやっています。

（S）基底細胞畠の症例です。

82歳の女性で、肛門部に出血があり、イボ状のものができて、排 便時に持が脱出するということで、切除しています。 melanoma と思ったのですが。

切除標本で、メラニンを増殖したマクロファージもおりまして、 色素を産出する基底細胞癌です。

（S）この症例は会陰部にできて帯状疮疹でS2からS4の仙髄が侵 されていまして、会陰部、仙骨部の疼痛があり、知覚鈍麻、膀胱は 尿閉を来し、直腸肛門でひどく tonusが下がって肛門静止圧が $5 \mathrm{~mm}$ 、 随意压が $18 \mathrm{~mm}$ と非常に著しい肛門不全を起こしています。

脊能の後方にヘルペスの zoster virusが潜んでいて、4、50年する 
と抵抗が弱ったときに出てきて皮膚にいろんな病変をつくるわけで すけど、それと同時に㝓髄の後方から出て骨盤神経叢を侵して、そ こにきている直腸と膀胱には粘膜にびらんを起こしたりいろんな障 害、尿閉とか肛門不全を起こすわけです。

診断は局所の臨床所見で決めており、治療は抗ウィルス剂で、ア スクロビルの内服。鎮痛剤をやったりとか、局所面には同様の軟稁 を投与しています。

（S）診察手順を自分別につくって、局所を診察の時によくながめ ることが大切です。単純な湿淩皮周炎だったらいいんですけども、 その典型的な例を頭に描いていろんな、真菌じゃないか、カンジタ じゃないか、カビ類のほかに昆虫類を疑って。一番手っ取り早いの は視診で診察した後に、培養もありますけど、私は主に生検し、こ れでかなりわかります。ホルマリンに組織を入れればカビもわかる しダニもわかりますし、組織診でいろんな特殊染色もできます。

（S）荷性化溶液を使った直接鏡検が、皮周科で最も多く使われて いるということで、落屑、鳞屑を採取してそれに10ないし40\%の 荷性化溶液を落として、そこにカバーグラスをかけて乾かして見る ようにします。

（S）当院での治療といいますと、肛門疾患、直腸疾患に原因した 続発的に起こったものは、原因疾患を取り除く。ほかのはっきりし た感染源とか病原が明らかなものはそれに準じた治療をするわけ で、その診断が大事なわけです。一応真菌とか昆虫とか細菌とかい ろんな病原体がありますから、それを特定することが一番大事だと 思います。

以上です。

司会フロアから何かございますか。

黒川（彰夫・黑川梅田診療所）坂田先生と佐々木先生に扔伺い したいんですが、最初の真菌症の中でSTDが何\%ぐらいあったの か、コンジローマに関しては尖圭コンジローマ64例中41例がSTD。 ヘルペスが59例中 40 例ですから $67.8 \%$ 。大体 $70 \%$ 近くがSTD。そ れまでそう聞いてなかったときにはすべてが10\%程度だったんで す。ところがアナルセックスがないかと、その気で聞きますとかな りの率でSTDが多い。だからその聞き方で全然患者さんの対応も 違うということで、その边調べられているのかどうか。

坂田 やはりなかなか聞きづらいところですね。

接触とかいろんな、たとえば異常な perianalとか perioralとかそ ういういろんな、なかなか難しいんですよね、細かいところまで聞 くには。

黒川 そう詳しくは扮聞きにならなくていいんですが（笑い）、 同性問での接触があるかどうか。それからへルペスに関しては渡航 歴。

司会 皮虐科の鳥居先生にそのあたりを簡単に。

鳥居 STDか否かということは非常に大事な問題だと思います。 確かに感染の問題があるのでそのために治療が2倍本来必要になる ものなので。おっしゃられたように疾患によって明らかにSTDじ やないものというのもあるわけです。ヘルペスの場合は単純へルペ スのII型というのがSTDが多いといわれていますが、带状疮疹は STDではないわけですね。ただ、一番最初のごく初期にperianalに 水疮が出た場合はduplexのことがあるので、それはパートナーの ことを聞くということは必要だと思うんです。コンジローマに関し てはこれはむしろほとんどSTDだと思います。

司会 次にいきたいと思います。「心身症によってIBSとなり、 肛囲皮夙炎に尖圭コンジローマを併発した一例」大腸肛門病セン ター高野病院の久野先生、よろしく打願いします。

久野（三郎・大腸肛門病センター高野病院）（S）今回精神的 ストレスから下剂を乱用し下利型IBSとなり、肍門周囲皮周炎にさ らに尖圭コンジローマを併発したと考えられる症例を経験しました ので報告致します。

症例は22歳女性で、主訴は肛門周囲の小腫瘤です。現病歴とし ては平成14年の6月頃からいろいろストレスがありまして、不安が
強くなって、市販のスルーラックという下剂を1日100錠ぐらい飲 むこともあった。15年の 10 月ぐらいから下痢型になり、水様便が 日5ないし6回あった。今年の 2 月ぐらいから肚門周囲に小腫瘤を触 知され当院を受診、尖圭コンジローマということで入院後仙骨麻酔 下にこれを切除、焼灼し、経過は良好です。

今回は精神的なストレスで下凨乱用ということで尖圭コンジロー マとの因果関係が、ちょっと解釈が難しいところもありますが、こ ういう症例を経験して、インターネット等で調べましたところそう いう症例は特別に見られず、当院の1982年からの 22 年間での尖圭 コンジローマ158例中でもこういう病歴はちょっと聴取できない状 態でした。

司会 鳥居先生が先ほどコンジローマはSTDだと言っておられ ましたが、このような症例ではいかがでしょうか。

黒川 鳥居先生に逆らって申しわけないですけど、どうしても STDでない尖圭コンジローマが肛門科においては結構ございます。 先ほどSTDが約69\%で、ほかの人たちはどう考えてもSTDとは思 えないんです。そういう方々の多くが下揦をなさっています。しよ っちゅうお尻を洗ったり、お尻がいつもヌルヌルしている。ですか らこういうケースではストレスから、心療内科的に起こってきたか は別にして、下痱ということが1つの誘因になってたことはあり得 るかなと思いました。心身症と下痢は関係ないんじゃないかとは思 います。

久野 100 錠飲むというのが通常では起こり得ませんし、こうい うのがepisodicにと申しますか、ストレスがかかるたびに繰り返さ れたような状態があったみたいです。

司会次に「尖圭コンジローマに合併した肛門疾贅癌 （verrucous carcinoma）の一例」を東葛辻仲病院の堤先生にお願い します。

堤（修·東葛过仲病院）（S）今回われわれは巨大な尖圭コン ジローマに肛門部皮膚病唯癌を合併し、結果的に切除を施行した1 例を経験したので報告します。

（S）症例は67歳、男性。約 10年前に肛門部皮虚の腫瘤に気づい たものの放置していました。約 2 年前よりかゆみの出現とともに腫 瘤が急速に増大し始めたために当院を受診しました。

入院時の所見です。腫瘤は $12 \times 8 \mathrm{~cm}$ 大でイボ状を有しており、 一部に易出血性のびらんを形成していました。

びらん部位より一部切除生検した結果、表皮内に強く增生した高 分化の squamous cell carcinomaの所見を得ました。また潜出液の 培養検查でヒト乳頭腫ウィルス VI型が同定されたため、尖圭コンジ ローマに合併した肛門部皮虔病贅癌と診断し、外科的切除の方針と しました。

（S）手術は腰椎麻酔下に腫場より約 $20 \mathrm{~mm}$ 離して広範囲に会陰皮 虚、皮下組織を切除し、皮下外括䄪筋は完全に切除、浅外括的筋の 一部を切除しつつ、正常移行上皮部分を一部環状に切離しながら腫 湟を摘出しました。残存肛門皮店と内括約筋と皮膚を释合しました。 欠損部に形成外科的に皮周弁を充填し、手術を終了しました。術 後46日目に大きな術後合併症もなく退院となりました。

(S) 摘出標本の肉眼的所見で、 $12 \times 8 \times 4 \mathrm{~cm}$ 大で中央部に肛門部 の欠損部を認め、表面は凹凸の粗大結節粎で、色調は淡黑褐色から 乳白色調まで様々でした。

（S）切除標本の病理所見、びらん部にコンジローマの角化に付随 した高分化の squamous cell carcinomaが真皮上層から樑層まで認 められました。皮下脂肪組織には達しておらず、切除断端の癌は陰 性でした。びらん部における抗HPV抗体を用いた免疫染色は陰性 でした。

（S）本邦における肛門周囲巨大コンジローマは調べ得た範囲では 自験例を含め 17 例で、その治療法は外科的切除、凍結療法、電気 焼灼術、5Fu軟高、フォドフェリン外用などが試みられています。 悪性の病変は外陰部から肛門に波及した例と自験例のみでした。尖 圭コンジローマの悪性化に関してHPV16型、18型などがハイリス 
クで、通常見られるHPV6型、11型はローリスクで一般に発癌性は ないものとされています。今回われわれが経験した症例では癌が検 出されたびらん部より HPVは検出されておらず、癌の発生過程に 尖圭コンジローマが関与していたかははっきりしませんでした。し かし直腸内に発育し、扁平上皮癌を合併した尖圭コンジローマで HPV6型のみが検出された症例の報告もあり、腫瘍を形成するよう な大きな尖圭コンジローマにはHPVの型解析を含む組織学的な評 価を踏まえた治療法及び十分な経過観察が必要と思われました。

以上です。

司会 何かご質問ございますか。

山名（哲郎・社会保険中央総合病院）この患者さんはHIVの感 染というのは。

堤 陰性でした。

山名 先生言われましたが、この症例でHPVの同定をされて6型 であったと。ほかの型はでなくて。

堤はい。出ませんでした。

司会これはいわゆるBuschke-Löwenstein tumorという名前が ついていますが、小さい尖圭コンジローマがあのように大きくなる のか、もともと別の性質か、そのあたりはいかがですか。鳥居先生 にも教えていただきたいんですが。

堤 巨大という大きさの規定というのはわからないんですけど も、やはりコブシ大に見えるとかその程度だと思うんです。 Buschke-Löwenstein tumorといわれるものとコンジローマという のは発生がまだ、本当にコンジローマから大きくなったものかある いは全く別なものかというのは、わかってないんです。

鳥居やっばりHPVのタイプによって随分違うと思うんです。6 型、16型、悪性度がどんどん上がっているものに関しては、昔は giant condylomaというのは verrucous carcinomaに入るような概念 であったんだと思うんですが、いまはやっぱり臨床的なサイズより はタイミングで癌化するかどうかを見るのが塞際的だと思います。 基本的には外方浸透型のSCCで、下に浸潤してこない、metaをし たりとかどんどん梁く入り込んでくることが比較的少ないもので す。わりとSCCの中では扱いやすい方だと思っているんですが、先 生の症例みたいにずっと下まで落ちていくというか、真皮が落ちて いくというよりは肛門の中に入っていくという意味だと思うんです が、それは私も初めて見ましたので、どうもありがとうございます。

司会 続いて「Pagetoid spreadを伴う肛門管腺癌の一例一鑑別 診断についてー」で砺波総合病院の小杉先生、よろしくお願いしま す。

小杉（光世・市立砺波総合病院）（S）これは2002年に大腸肛 門病学会誌に出しましたが、今回Paget病との鑑別というところに 焦点を合わせて発表させていただきます。

(S) 症例は53歳、女性で、受診 2 年半前から肛門部腫瘍とかゆみ があったということです。肚囲に境界明瞭な環状浸潤性紅色局面を 認め、術前診断はPagetoid spreadということです。臨床的病期は ステージ1です。ところが組織学的病期を見るとステージ $3 A 、 251$ 番のN1/4（+）でした。

（S）免疫組織化学染色を行うといわゆる extramammaryのPaget 病と Pagetoid spreadを鑑別できるというペーパーに触れまして、 一応検查しています。1つはGCDFP15、これはgross cystic disease flood proteinの 15 というものです。もう1つはCK7とCK20で、こ ちらの方は両方マイナスで、CK20がプラスであるということで、 Pagetoid spreadと診断されます。いわゆる extramammaryの場合 はこれが逆転するわけです。

免疫組織化学染色をしますとアポクリン、エクリン汗腺細胞に存 在する GCDFP15、こちらとCK20を利用して Pagetoid spreadと Paget病を篮別できるということです。それからCK7がマイナス、 CK20がプラスということで、結腸直腸腺癌の組織特異性として発 表されていて、私たちは今回こういう免疫組織化学的染色でもって それを確認できたということです。
（S）臨床的考察ですが、いわゆる乳房 Paget病と Pagetoid癌は、 同一疾患群というふうに考えられます。逆にいわゆる extramammaryのPaget病は今回のこういうものを検討しますと、 そちらの方がいわゆる皮唐癌で特殊であると考えます。ですから従 来は臓器がmamma と extramammaryというふうに私たちずっと思 っておりましたけれども、今回こういう1つの考え方もあるという ことで提示させていただきました。

以上です。

司会フロアの方から。

浅野（道雄・松田病院）

この患者さん予後はいかがだったんで

しょうか。

小杉 現在再発なく健康に過ごしております。定期的にフォロー アップして3年経過していますが、問題ございません。

司会 Pagetoid spreadは予後が悪く、Paget病は比較的予後がよ いという意味で鑑別は絶対しておかないといけないということです ね。

小杉 そうです。臨床的には extramammaryのPaget病は皮埥痺 であります。それから Pagetoid spreadは乳房Pagetと同様に乳房に も Pagetoidというのがあるんですが、それが同様に悪性度が高いと いう認識と、もう1つは肛門管及び直腸に腫瘍があって肚門周囲に 何らかの皮䖉疾患を見た場合に、こういうものがありますよという ことです。ですから腫瘍があって肛囲に皮疹がある場合はこれを考 えるということと、もう1つは外側にあった場合に直腸内に腫瘍が あるということも逆に考えなければならないということです。それ から手術に関してはマッピングをして取るということだと思いま के。

司会 直腸や肛門管に癌があってこういう皮周病変を見たとき は、免疫染色しなくても Pagetoid spreadと診断してはいけないん ですか。

小杉 私たちの症例は腫瘍もばっちりありますし、周りの所見も ばっちりありますので、これは臨床的にそう思っていいと思います が、微妙なところはやはり免疫組織学的検査をしなきゃいけないと いうことと、今後は肛門腺由来の疾患とどう鑑別するか。もし肛門 腺由来であれば、逆にいえば直腸側の上方進展もあり得るかなと思 っております。

岩垂（純一：社会保険中央総合病院）いまみたいに肛門の方に 癌があって、周辺のところにPagetoid spreadを疑わせるようなも のがあるときに、その切除の幅というのはどのくらいに。

小杉 Pagetはやはり境界が鮮明といいながら不鮮明なところも あるので、マッピングはPagetoidよりももっと $1 \mathrm{~cm} 、 2 \mathrm{~cm} 、 3 \mathrm{~cm} 、$ 場合によれば4cmまで確認すべきかなと思います。ただし、この Pagetoid spreadは私たちが見ましたところ、境界から $1 \mathrm{~cm}$ 離れた ところは全部ホガティブでしたから実際は $2 \mathrm{~cm}$ 離して取りました。 local recurrenceはありません。ですから Paget病と Pagetoidとは違 うんじゃないかと。

松田（保秀・松田病院） Pagetoid phenomenonといいますか、 非常に侵入してくるタイブとそうでない単なるPaget病というの は、肉眼で見ると深入を起こしたものはかなり時間的な経過で真っ 赤になったり色が薄くなったり非常に激しい色調の変化がありま す。それは私も何例か経験した病態なんですが、それから予後がき わめて悪い。後で話しすると思いますので、もう1度ディスカッシ ヨンを。

司会 次に「肚門周囲Paget病の検討」を松田病院の浅野先生、 よろしくお願いします。

浅野（S）本日の報告では典型的な3例をまず報告し、次に実 際に肛門管癌においてPaget現象がどの程度あるのかを検討してみ ました。

（S）症例 1 は 61 歳の女性。発症して 3 年間他院で保存的な治療を 受けていましたが改善せず当院を受診、治癒しないということで生 検をしてPaget病の診断に至っています。 
（S）局所の状態です。周囲に色素沈着を伴って、表面は比較的乾 燥したような感じ。

(S) Paget細胞が認められ、PAS染色でよく染まっています。

(S) 次は38歳、男性。この方はいわゆるPaget現象の方で、発症 して1年間してから当院を受診され、やはり1カ月間ステロイド軟 衰等を処方されていましたが、治潦しないということで生検して Paget細胞があるという診断に至っております。マッピング生検を 施行したりして、最終的にMilesの手術を行いましたが、その後 10 カ月の間にリンパ節転移、局所再発を来して死亡しております。

（S）マッピング生検したときの写真ですが、かなり発赤が強く、 こういう赤い状態を呈するときもあったんですが、もう少し目立た ないときもありました。先ほどのPaget病に比べると湿潤した感じ で、境界は比較的明瞭です。

（S）粘液に富む腫瘍で、表皮の方にPaget細胞といいますか、腺 癌の細胞の浸潤を認めます。

（S）次の症例は63歳、男性です。この方もPaget現象です。この 方は便潜血陽性ということで他院で内視鏡を施行されたときに肛門 の polypを発見されて受診されています。生検で高分化腺癌があっ たということで当院に来られ、まず経肛門的局所切除を施行されま した。このときに肚門周囲に広がる皮疹もありまして、ここを念の ために生検したところ Paget細胞があり、マッピング生検等を施行 したんですが、思ったほど出ないということで、この後もう1度局 所切除を施行されました。結局断端陽性で腹会陰式直腸切断術が行 われています。その後 3 年後に単径リンパ節転移を来し鼡径部郭清 を行い、現在 4 年経っておりますが、局所再発の疑いはありますが 生存中です。

（S）初診時ですが、このような白っぼい皮膚様で、内視鏡で反転 すると腫瘤を認めます。

（S）結局切除がなされました。メインの腫瘍はもう取られており ますので、メインの腫瘍はわかりません。

（S）ここが腫瘍の部分で、表皮の中にPaget細胞の浸潤を認めま す。

（S）先ほど小杉先生もおっしゃっておられましたが、Paget病と Paget現象は全く違う疾患というふうにとらえなければならないと 思います。 primary extramammary Paget disease と secondary いうふうな言い方をされるときがあります。 prognosisはかなり違 うということです。

（S）いまの3例をまとめてみますと、診断、治療の過程で幾つか それぞれ問題点がありまして、まずPaget病の方は病悩期間が 3 年 で、初診から診断確定までにも2カ月かかっているという点が挙げ られます。症例 2 は病悩期間が 1 年間、初診から根治術まで 3 月を 要し、予後はきわめて覀い。症例3では最初に局所切除がされてし まい、その後比較的いいかなと思っていたら時間が経ってから再発 しているという問題があります。

（S）小括 1 。診断については、なかなか治らない肛門皮疹の場合 はPaget病を念頭に置いて生検を行う必要がある。Paget病あるい はPaget現象の所見が得られた場合、肛門管や直腸の癌の存在を念 頭に置いて診断を確定する。肛門管や直腸に癌の併存を認めた場合 は、局所切除などで時間を費やすことなく迷わず直腸切断術を選択 すべきである。一方、そうでない場合はマッピング皮虔生検により 肛門機能温存の可能性を探る余地があります。

（S）そこで当院で行われた手術例の中で肛門管のある腫瘍で、全 部プレパラートを見直してみました。1989年1月から2003年10月ま でに当院で切除された肚門管腺癌 23 例で、侍瘦癌は除いておりま す。

男 15 例、女 8 例。手術は直腸切断術が 17 例、経肛門的切除術が 6 例。

（S）見直してみると、先ほど提示した症例 2 と症例 3 を含めて 23 例中 4例にPaget現象を認め、比率は $17.4 \%$ したた。この中には直 腸切断術をされたものもありますので、経肛門的切除が行われた肛
門管癌だけに絞ってみますと、6例中 3 例で50\%でこれは何を示し ているかというと、経肚門的に取れそうな小さなものが危ないとい うことになります。

（S）症例を提示しますが、この方は 80 歳の男性で、Rb-Pの 15 ミ リの II a病変を経肛門的に一括切除されております。深達度はsm2 です。この方はsm2でしたので追加切除を勧めたんですが、80歳と 高齢ということで手術されませんでしたが、その後4年後に単径り ンパ節転移、肺転移を来して死亡して扔ります。

（S）この4例をまとめてみると、全例深達度 smでした。肛門管 腺癌が多く、1例が粘液癌。このような予後になっています。

かなり乱暴ではありますが、Paget現象のなかったものとあった もので生存曲線を描いてみました。赤で示したPaget現象プラスだ ったものはすべて sm癌だったことを考えると、かなり子後が悪い といっていいと思います。

(S) 肛門管癌の $17 \%$ \% Paget現象を認め、その症例の原発巣の深 達度はすべて smでした。肛門管癌の表皮への進展は（予後）の1つ になる可能性が示唆されます。

（S）最後に本邦報告例について集計してみました。

文献上判断したものも含めてPaget病とPaget現象に分けてみる と、ほほ半数ずつありました。年齢と男女比は変わりありません。

（S）初診時の主訴ですが、Paget病の方はびらん、皮處痒とい った皮膚の症状が主だったのに对して、Paget現象の方は肛門痛と か出血といった胿門症状が多かったのが特徴です。

（S）皮膚病が診断された時期ですが、Paget病の方が初めから Paget病だと診断されておりますが、Paget現象の方は手術後に発 見されるものが半数を占めていました。

（S）術式はPaget病では局所切除が行われたものが半数以上あり ましたが、Paget現象ではほとんどが最終的に直腸切断術が行われ ていました。

（S）まとめです。Paget現象は治療、予後などを左右する重要な 所見であるが、視診上見逃されやすいので、その存在を念頭に置い て十分注意して日常診療にあたる必要があります。

以上です。

司会フロアの方から何か。

吉永 皮豦変でPagetを疑った場合、生検の仕方は、無麻醉で 内視鏡の鉗子みたいなもので取るのか、あるいは局所麻酔してある 程度何力所か取るのか教えていただきたいんですが。それとも腰椎 麻酔で取るんでしょうか。

浅野 最初に診断をつけるときはほとんど外来で行いますので局 所麻酔です。通常は1ヶ所か2ヶ所。

小杉 データを示していただいたので非常に参考になりました。 肛門管腺癌の17\%に Pagetoid phenomenonがあったということで、 肛門科医、臨床家医とすれば小さいものでもしっかり見るというこ とが重要かなというふうに思いました。それから17\%以上の率で あるということであれば、肚門管癌を見たときはぜひそういう Pagetoid spread、があると思った方がいいかなというふうにも思 いました。もう1点ですが、 phenomenonという言葉と spreadとい う言葉を使っているんですが、私がspreadという言葉を選んだ理 由は、あれは癌ですので単なる phenomenonじゃないという意味で あえてspreadを選らばせていただきました。

坂田 Paget phenomenonですが、連続性の内容の標本もちょっ とあったようですけども、そういうのも実際あるんでしょうか。原 病巣からダイレクトに。

浅野 連続性はあると思います。

黒川 連続性があるないの話ですが、spreadしているという表現 を使いますが、連続性を連続切片で切っても見つからないケースが 結構あると思うんです。ですから連続性があるとは言い切れないと。

岩垂 そうすると結果的には局所切除できるような肚門管癌の小 さいものがあったときというのは、かなり気をつけないといけない ということですか? ?の周辺の皮虔病変というのをよく見て、ちょ 
っとでも疑わしい場合はそこを必ず含めて取っておきなさいという ことですね。いまの括ですと連続性もよくわからない、というこ とになってしまうと切除標本を出しておいて、断端マイナスという ことで喜んで、しばらく様子を見ているうちにまたまた単径リンパ 節が腫れてきたりする危険性もあるというようなとらえ方でよろし いんですか。

浅野 まさにそうだと思います。むしろ比較的大きな腫瘤を形成 してもう迷わずMilesにせざるを得ないようなものは、それほど spreadしてないというふうな結果でした。

岩垂 そうすると肛門管癌は何でもかんでも全部Milesやってと いうような乱暴な論調になってしまうので、それはちょっとおかし いと思うので、医学的に何か直腸切断術にすべき例とそうでない例 というのをクリアに分けていかなきゃいけない。皮膚病変の方がそ んなに赤っぽくなければそんなに気にしなくていいということでよ ろしいんですか。

浅野つまり皮居に注意しましょうということに尽きると思うん です。

岩垂 松田先生先ほどおっしゃいましたよね。全然色が変わって しまったり、まるっきり正常に見えたときもあったような言い方を されていたけど。

松田 岩垂先生の質問ですが、とにかく色調の変化は一番最初に 見たとさは普通の肚囲湿疹のように薄く皮䖉炎を起こしているかな という程度です。それから砕石位にしたりなんかしていろいろ刺激 を与えますと、そのせいもあるのかもしれないけど、真っ赤になっ たり色が薄くなったり、かなり変化が激しかったですね。それと私 2例経験しているのはマッピングやりますよね。生検して深いとこ ろまで取ったこともあったんですが、そうすると 2 例とも䋃径りン パ節転移が急激にくる。だからそれはよくいわれる malignant melanoma と同じように急速な進展というのがあり得るんだと感じ ているんです。

司会 続いて「会陰部の注意す心゙き皮周疾患一皮凨科からのメッ セージー」ということで内田病院の江内田先生お願いします。

江内田（智子.内田病院）（S）今回私たちは会陰部の主な皮 䖉疾患、特に注意すべき皮虞疾患を紹介させていただき、その診断 のポイントについても簡単に触れていきたいと思います。

（S）まず初めに乳房外Paget病ですが、この疾患はアポクリン汗 腺由来の表皮内癌です。これに対してPaget現象とは直腸、肛門管 などの隣接臓器の腺癌が表皮へ連続的に浸潤したもので、皮周原発 のPaget病とは区別されます。発生場所は圧倒的に外陰部が多く、 次いで腋下、肛囲、まれに体部に発生します。数力所に多発する例 もあり、ほかの部位にも皮疹があるかどうか注意して見る必要があ ります。初期病変は陰部の慢性湿疹、間擦疹や陰股部白痛などと鑑 別が難しく、そのため誤診されやすいですが、初期の紅斑の段階で は組織診断以外に鑑別する方法はありません。したがって進行して 浸潤癌となってから皮周科に紹介されてくる患者さんが多くいま す。組織像を示しますが、このように表皮内に胞体の明るい大型異 型細胞形成する像が特徴的です。免疫染色ではCAが陽性です。

(S) Paget病発生初期の紅斑は鳞屑やびらん、色素沈着や色素脱 出を伴う非特異的な紅斑であるために、湿疹などと非常に鑑別が難 しいです。確定診断のためには組織診断が必要になります。病期が 進行してきますと隆起性病変を形成してきまして、Paget癌と呼ば れる浸潤癌になります。

（S）Bowen様丘疹症は外陰部に黒褐色皮疹が多発しますが、組 織学的に悪性で、表皮内癌であるBowen病と同じ組織所見を示し ますが、本質的にはヒト乳頭腫ウィルス感染症なので悪性化はしま せん。好発年齢はBowen病と比較すると20代から30代ぐらいのや や若い人に生じます。予後は良好で、経過中自然消退することもあ ります。治療は尖圭コンジローマと同様に液体窒素を用いた凍結療 法などを行います。

（S）表皮内癌であるBowen病が外陰部に生じることもあります。
年齢は60代以降の高齢者に多く見られます。臨床像は表面にびら んや角化、鱗首を伴っていて、色は紅色から褐色まで多彩な色調を 示します。びらんが目立つ場合には光沢のあるいわゆるビロード状 の臨床像となります。Bowen病もPaget病のように臨床所見からは 慢性湿疹や白痽症との区別がつけにくく、やはり組織診断が必要に なります。

以上、会陰部に発生する皮虚疾患の代表的なものを供覧させてい ただきました。

司会 何かありますか。

久野 日頃確認したいことを何点かご指摘になったと思うんです が、カンジ夕、真菌症ですが、抗真菌剤などを塗ったあとのケアの ご指導なんかはどうなされているでしょうか。塗りっぱなしではど うしても部位的な解剖学的な特徴上基剤によっていわゆる接触性皮 周炎を起こすことがありますので、どんなものでしょうか？

江内田 あまり鳞屑が認められず明らかに通常の湿疹のような状 態の場合は、1、2週間の外用剤を使っていただいて、改善がない場 合は皮雇科をすぐ受診してくださいというふうに。

久野 真菌を疑って培養に出した場合の陰性が、本質ネガティブ と申しますか、その率に関してはデータご存じでしょうか。

司会 鳥居先生、教えていただけますか。

鳥居 最初の方の演題でお話ししましたように真菌はやっぱり採 取が非常にキーになってくるわけですね。残念ながら浸潤してグチ ヤグチヤになっているところを取っても出てこないことが多いと思 います。ケアについてということなんですが、確かに湿潤傾向が強 い場合に抗真菌剤というのはクリーム基鼡が多いわけですね。幾つ か軟膏基剤がありますが、これは浸透性をよくするために、基本的 に皮盛の外用剂は軟高がいいということになっているんです。これ は皮膚に対する保護という作用もあるし、皮埥を保護するいろんな 面で油性基剤がいいはずなんですが、真菌郕に対してだけはびらん 面があるにもかかわらずクリーム基剤が多い。これは浸透性をよく するためにやっていることなんです。結局われわれが実際にどうす るかというと、亜鉛化軟膏という収斂作用があって、ちょっと軽い 消炎作用もあって、1回皮膚を乾かすというか、あまりグジュグジ ユしているやつを少しすっきりさせて、皮膚を少し乾かすというか 調整してから抗真菌剤を使うことが多いと思います。

基本的には真菌というのはある程度の湿潤環境がないと生えない はずのものなので、その環境を改善してあげればよくなるはずなん です。これは水虫も本来そうなんです。ただ、実際はなかなか難し いので、抗真菌剤で真菌を样してしまうというのが治療ということ になるわけですが、局所の清潔を保つということが多分治療の8割 がたを占めると思います。ステロイドと抗真菌剂を混ぜちゃうとい うのは皮膚科以外の先生はよくされるんですが、あれは皮涌科専門 医としては、白黒はっきりさせて正しい治療法をとるというのがよ いと思います。

司会次に「肛門の痒みとカンジ夕」ということで松島病院の松 村先生よろしくお願いします。

松村（奈緒美・松島病院大腸肛門病センター）

(S) 肛門及びその周囲の㳯みは日常診療の中でしばしば遭遇する 症状で、全身性疾患に原因があり、皮膚面に他覚的所見の少ないい わゆる特発性瘦痒症と、肛門部や性器の疾患による二次的症候性瘦 痒症に分けることができるといわれております。

原因としては、一番多く見られるのは肚門周囲皮覤の炎症で、接 触性、間擦性皮䖉炎や湿疹、真菌性皮膚炎などが挙げられます。治 療法は原因により異なりますが、いずれの場合も肛門衛生が大切で あると一般に考えられております。

（S）カンジ夕培養は水野・高田寒天培地で行っており、陽性の場 合はこのように黒色、数日で黒っぼい斑点状にカンジタが見受けら れます。

当院では肚門の痒みを訴えた患者にはほぼ全例にこのカンジタ培 養検查を施行します。1994年から96年までは年間 3700 件前後でし 
たが、1997年以降その数は滅少し、現在年間 2800 件前後となって おります。

（S）カンジタの陽性率は10年前には年間平均で $26 \%$ 前後でした が、1990年に17\%に減少。それ以降は $20 \%$ 前後でほほ横ばいです。

(S) 肚門衛生の観点の1つとして内閣府発表の洗浄機能つき便座 の普及率を扔示ししたいと思います。1993年には14.2\%であったも のが昨年2003には51.7\%というふうに報告されております。

(S) 10 年間で月別の検查数をグラフにいたしました。夏にやや多 い傾向が見られますが、ほほ月、季節によりそれほど大きな件数の 変動は認めませんでした。

（S）月別のカンジ夕陽性率です。やはり一番多いのは8月で $30.8 \%$ 。低いのは 1月で $14.2 \%$ 。夏に高く冬に低いという傾向が見 られました。

（S）カンジ夕陽性率はやはり 1994年と2003年で月別に調べまし たところ、8月が一番多いという傾向は変わりませんが、1994年時 で44\%程度の陽性率であったものが2003年には30\%程度と減少し ております。

（S）まとめです。当センターにおける過去10年間の肛門瘦轩症 とカンジ夕に関するデータを提示いたしました。1997年を境にカン ジ夕培養検查数、すなわち癌痤数というふうに考えてもいいかと思 いますが、年間約 3700 件から約 2800 件へ減少。カンジ夕陽性率も 年間を通して約 $26 \%$ から $20 \%$ へ低下いたしました。検查件数、

瘦痒症数は男性に全年で多く見られましたが、カンジタの陽性率は 男女間に差を認めませんでした。月別の検査件数の検討では、10年 前と比較し、㾦症の患者数は男女とも冬では隇少しておりました けれども、夏ではこの10年間、将を訴える患者数はほとんど変わ っておりませんでした。

以上です。

司会 肚門瘦痒症でこのカンジ夕に関するきちっとしたことをや っておられるのは先生のところだろうと思います。何かございます か。

过（順行・豊島園大腸肛門科）男性と比べて女性が少ないとい うのは、女性の場合はやっぱり盖恥心が男性と違って強いんじやな いかと思うのですがいかがでしょうか？

松村 先生のおっしゃる通りだと思います。当院では男女数が男 性 $55 \%$ 、女性 $45 \%$ 程度ということになっているんですけれども、 ただ、その $55 \%$ 、45\%と比較しても、瘦症は男性が $60 \%$ 、女性 40\%ですので、やはり率としては男性の方が高いということは今回 のデータでは一応出ました。あと女性が少ないのはひょっとしたら 婦人科の方で診ていただいているとかそういったことがあるのでは ないかというふうに考えております。

鳥居 いま気がついたことなんですけども、婦人科でカンジタと いうのはよく言われるわけですね。カンジタというのは湿潤したと ころにできやすいので、日和見感染は別として、特にcompromised な人じゃなくて抗生剤の乱用ぐらいで、皮用のカンジタができるこ とはまずないと思うんですね。純粋に皮虐のカンジ夕というのでは なくて、肚囲のというのはやっぱりちょっと特殊な状況があって、 腸管内常在菌としてのカンジタとのからみがもしかしたらあるんじ やないかと思うんです。私は肚囲のカンジタの専門ではないのでわ かりませんが。

坂田 実は私、30年前この会で湿疹群を水野・高田培地で調べた んです。40\%ぐらい陽性に出るんですよね。それがみんなカンジ夕 による皮青炎かはっきりしません。消化管の常在菌があるというか、 外科からするとカンジ夕症にしていいかどうかと考えます。

司会 次に「四囲の皮膚炎の原因分類について」を畑川クリニッ クの畑川先生よろしくお願いします。

畑川（幸生・畑川クリニック）（S）とりあえず肛門周囲皮庴 炎の原因を探ってみるということを考えてました。STDを発症す ることもあるし、種々の腫瘍もあるということであります。それか ら成書には肛門瘦痒症という言葉が扱ってありまして、皮䖉炎の原
因は何だということは書いてないわけです。いわゆる特発性の肚囲 疼凊症と呼ばれるものもあるかと思いますけども、全身疾患として はここに挙げるものがあります。

（S）皮豦変としては皮着炎、それから特異的炎症であるSTD だとか結核、腫瘍性病変、それからただいま申し上げました特発性 の肚囲瘦痒症などが考えられます。

（S）それで私は試案として1から6まで考えてみました。その徣 特異性炎症があって、STD、梅毒、HIV、それから結核なんかもあ り得る。物理的刺激による肛門周囲皮串炎、これは隅越先生がおっ しゃいました高度皮垂でトイレットペーパーでふき過ぎるというこ とですね。それから黒川先生がおっしゃっていますいわゆる洗い過 ざということもあるんだろうと思います。それから温熱刺激による 皮膚炎。物理的ですからそういうことも考えて、高温刺激であれば 熱傷、低温刺激であれば凍傷ということになります。それから掻爬 ということも物理的刺激になるだろうと思っております。

（S）症例ですが、便秘に対する洗腸キットを用いて高温のために 生じた皮膚炎、これが洗腸器具で、この部分が皮膚炎です。大腸に も大腸炎を起こしていて、S状結腸までこのような潰瘍が起こって います。

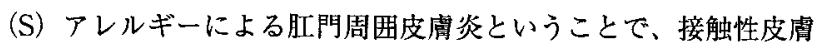
炎ですね。これはセッケン、薬剤と言っていましたが、これと先ほ どの化学的なものがほんとに違うのかどうかということですね。肛 門周囲の一次的な抗原刺激により抗体が形成されて、局所に強い炎 症が成立する。これがいわゆるアレルギーです。

（S）皮膚を見るだけではよくわからないということですね。基本 的治療は原因の除去です。それから要するにセッケンでかいたり、 薬をやめたりすればいいと。真菌感染を合併していないという自信 があれば、副腎皮質ホルモン、僕は使っていいんじゃないかと思っ ています。

（S）真菌感染を合併したもの。これステロイド剤で一時的に改善 したように見えても再発する。初診時真菌感染を疑って原則的に真 菌培養を行っています。私どもは簡易培養に出して、それを同定培 盖に出すということです。それから鏡検もします。病理組織も必要 なら取りますということで、先ほどありましたPagetのようなこと も含めて肛門周囲の皮成の問題については、やはり生検もかなり視 野に入れておかなければいけないんじゃないかというふうに考えて おります。

(S)これはKOHの candida albicansです。これがパーカー $\mathrm{KOH}$ こういうようなことを簡単にやれるといいんですが、なかなかでき ません。

（S）簡易培地法というのを用いますと、4日間で出ます。

これは candida albicansが証明された例です。

病理取ってみますと炎症細胞浸潤を認めるということで、PAS染 色でこの部位に菌糸と胞体を認めています。

（S）真菌検出率は、私ども1999年1月から 2004年、今年の2月ま で、肚門術後感染例を除いてカンジ夕簡易培地で行いまして、これ 水野・高田だったと思いますが、真菌検出率は95例、15.8\%です。 それから真菌同定率、これさほって十何例同定できなかったので $76.8 \%$ ずす。

（S）真䒩感染を合併した肍門周囲皮虐炎、とにかく私は、乱暴で すが、皮覤炎を見つけたらステロイドをまず塗ってみます。真菌感 染を同時に、たとえば生検をしたり培養したりして感染を確認して から、ステロイド剤と抗真菌剤の併用がより有効なように、短期間 で治せるようにどうも考えられます。抗真菌版だけですとなかなか 取れない場合があるんじゃないかというふうに考えています。

(S) 細菌感染、これがばかにならない。真菌との混合感染はない んだろうと思うんですが、真皮の露出所見、ちょっと掘れていると いうことです。治療には抗生剈の内服がいいんではないかと。

（S）まとめですが、肛門周囲の皮病変について自験例を summarizeしました。肛門括約筋弛緩の際の腸内容の少量の漏出が 
最も大きな一次痒の原因と考えられる。要するに肛門疼痒症です ね。掻爬刺激による二次病変としての肛門周囲皮虑炎には種々の病 態があります。病態に応した治療が肝要であると考えます。

司会 何かございますか。

黒川 鳥居先生にお聞きしたいんですが、先ほどからカンジ夕、 カンジタというお話が出てきているんですが、私、先ほど言いまし た肛門の真菌症の話を調べたときにカンジタはこんなにベラボウに 多くないんです。それについて先生ちょっとコメントいただければ と。

鳥居 私10年以上皮周科医やっていてお尻の皮凨病でこんなに 盛り上がったことはないので（笑い）確かに、実は演者の先生が 出された培養の細菌とかウィルス感染とかも含めてちょっと感じた んですが、やはり便とのからみとか腸内の常在の菌との問題がある ので、私皮虐科の立場で真菌のタムシとか水虫とかいっぱい見てる わけですけど、普通にカンジタができる、肚囲以外に爪の周りにで きたりとか脇にできたりいろいろするわけですが、基本的に鏡検反 応を大事に考えるんですね。肛門科の先生方が鏡検はなかなか実際 にできない状況のケースが多いと思うので培盖を行うんだと思うん ですが、それでカンジタが出た場合にいわゆる colonizationなのか、 びらん面があって病原性がない、ただ表面でcolonizationを起こし ている状態なのか、 infectionとして起こしているのかということは なかなかが難しいところがあるんじゃないかなという気がします。 培盖でやればカンジタが圧倒的に多いのかもしれませんが、やっぱ り実際肛井で真菌症で見られるのは糸状菌とかほかの菌も、病気と しての真菌症という意味ではinfectionとしてはカンジ夕以外のもの も結構あるんじゃないかと。

久野 先生のところでのステロイド剤としてはファースト チョ イスとしては何を使っていらっしゃいますか。

畑川 最初はウィークネスを使っていました。

久野 業者に聞きますとリンデロンVGの基㓮が非常に皮膚にや さしいというのがあったので、私たちも使用しているんですけれど も。あとケアですが、塗りっぱなしで指導されますか。それともガ 一ゼをその後詰めたりの指導をして、湿潤層にならないようにと。 どんないい薬であってもやっぱり湿潤を増強する可能性があるから と聞いているものですから。

畑川ケアの件については先生に勝る先生はいらっしゃらないん だろうと思うんですね。私どもはやはり診断だけつけて、後は何か やってもらえるだろうみたいな感じが強いものですから。それから やはり皮周科の鳥居先生もおっしゃってましたように、乾燥させて おくということが問題だろうと思います。带鉛化軟高なんかを使う こともありますし、非常にいい手だなと思っています。それからな んか抹茶を使われる先生もいらっしゃるそうで。

司会どうもありがとうございました。本日、勉強しまして肚門 を診察するのに目で見て指でさわるということが一番大切とよくわ かりました。それからご多忙のところ、鳥居先生には他科のこのよ うな勉強会にお力添えいただきましてほんとうにありがとうござい ました。皆さまから厚く御礼申し上げたいと思います。(拍手) 